\title{
How Britain Underdeveloped Bechuanaland Protectorate: A Brief Critique of the Political Economy of Colonial Botswana
}

\author{
Monageng Mogalakwe*
}

\begin{abstract}
Britain declared Bechuanaland a 'protectorate' in 1885 in a move largely driven by military strategic considerations rather than by the availability of economic resources. This can give the impression that in Botswana the process of economic underdevelopment, that is often associated with colonialism, never took place in this British 'protectorate'. This article reveals that even in the so-called 'protectorate', the British colonial state policies subverted indigenous economic interests and stifled opportunities for indigenous private capital accumulation, while actively promoting the economic interests of a small white settler capitalist class.
\end{abstract}

\section{Résumé}

En 1885, la Grande-Bretagne a conféré au Bechuanaland Je statut de " protectorat », principalement dans une optique militaire stratégique, plutôt que du fait de la disponibilité de ressources économiques. Cette situation peut amener à croire qu'au Botswana, le processus de sous-développement qui est souvent associé au colonialisme, n'existe tout simplement pas dans ce " protectorat » britanıique. Cet article révèle plutôt que même dans ce soi-disant « protectorat », les politiques de l'état colonial britannique ont porté atteinte aux intérêts économiques indigènes et constitué un frein aux opportunités d'accumulation de capital privé par les indigènes, tout en défendant activement les intérêts économiques d'une classe crpitaliste réduite composée de colons blancs.

\section{Introduction}

It is common cause that there was a direct relationship between the expansion of European industrial capitalism and European imperialism and colo-

* Department of Sociology, University of Botswana, Gaborone, Botswana. E-mail: mogalakwe@mopipi.ub.bw. 
nialism. Colonialism can be defined as the implantation of the metropolitan state apparatus in a conquered territory, or as the exploitation and oppression of one riation by the ruling class of another nation (Lenin 1968). Colonialism was primarily an economically driven process to find new sources of raw materiais and markets for European industries. At the outset, colonialism was in the form of foreign ventures by mercantile capitalists, and culminated for Africa in the infamous Berlin Conference of 1884-1885. This Conference laid the ground rules whereby European powers would allow each other to divide up the 'African Piv', and by 1900 there was scarcely a corner of Africa that had escaped European rule, Liberia and Ethiopia being the only exceptions (Wallerstein 1961:30). The Berlin Conference agreed, inter alia, that any European nation that took possession of any part of A frica or named themselves as a 'protector' of one, had to inform the other signatories of the Berlin Act of this action and that if this was not done their claim would not be recognised (de Courcel 1988).

With reference to British colonialism, a number of factors seemed to have influenced the formulation of British imperial policy. These factors included military strategy and supremacy, economy, superficial humanitarianism and respect for the white colonial aspirations (Maylam 1980). In the case of Bot-swana, Britain was not attracted by the availability of raw materials and other economic resources, but rather by the strategic military consideration in the region. This article argues that although Britain's colonisation of Botswana was motivated by strategic military interests, nonetheless, the colonial state administration actively promoted the economic interests of a small white settler community whilst simultaneously subverting indigenous Tswana economic interests and destroying the opportunities and incentives for indigenous private capital accumulation by the Tswana. As a consequence of this, at the time of Botswana's Independence in 1966, the country did not have the nucleus of an indigenous capitalist class. Botswana's present capitalist path did not grow organically from pre-colonial Tswana civil society, but was imposed by the departing colonial power. The article starts by briefly examining Botswana's pre-colonial economy and then moves on to examine Botswana's economy under colonialism. The article shows how the British colonial state, representing the interests of settler capitalism, subverted and undermined the Tswana economy and society. Finally the article examines the arrangements that were made by the departing colonial state officials for political independence, and reveals that these arrangements were designed to keep a 'politically independent' Botswana within the ambit of international capitalism. 


\section{The Tswana before colonialism}

The Tswana are found in the interior of the Southern African sub-continent, mainly in present day Botswana, and in the North West and the Northern Cape Provinces of South Africa. They are a part of a larger Sotho-Tswana linguistic and cultural sub-group of the Bantu people of Southern Africa. Archaeological investigations indicate that the Tswana were probably setthed in this area as early as 450 A.D. (Campbel] 1968). The origin of the name Batswana has been variously interpreted to mean 'the little off shoots from $t s w a$, to go out, or to come from, or the name could mean separatists or seceders, (from tswaana), but it could also mean 'those who are alike' (from tshwana) (Schapera 1984). What seems certain, however, is that three of Botsviana's so-called 'principal tribes', namely Bakwena, Bangwato and Bangwaketse, can trace their descent from one legendary ancestor, Masilo, who is thought to have lived between 1460 and 1560. Masilo had two sons, Mohurutshe and Malope. Malope had three sons, namely Kwena, Ngwato and $\mathrm{Ngwakeste}$, from whom the names of three of the Tswana groups derive (Tlou 1974). After the death of the legendary Masilo, Malope's three sons separated from Mohurutshe to form their own chiefdom, the Bakwena, in South Eastern Botswana in 1650. It would seem that the Sotho-Tswana group became prone to periodic fission whereby a brother, a son or one faction of the royal family would challenge the political position of another for control of the state. There was also a tendency for the unsuccessful faction leader to secede and move away with his followers to a new locality. For example, in .1730 , Ngwaketse spilt from Kwena and established his own chiefdom. Ngwaketse was followed by Ngwato who split from Kwena in 1750 , followed by Tawana who later split from Ngwato in 1795 and established his chiefdom in the North West of the present-day Botswana (Legassick 1969; Tlou 1974).

Tlese lineage clusters of separatist chiefdoms all claimed equal status with each other and remained militarily weak and suffered military aggression from the Boers who had recently arrived in Southern Africa and wanted to expand further north. According to Ramsay and Morton (1996) there were however isolated cases of military alliances between the Chiefs, such as in 1864 when the BaKwena, BaNgwaketse, and the Barolong threatened the South African Republic ivith joint military action if the Boers seized Bahurutshe land. In 1883, the Barolong, BaNgwaketse, BaKwena, and BaKgatla-ba-ga-Kgafela renewed a defensive alliance in the face of Boer aggression against Barolong. It can be argued that these military pacts could have marked the beginning of a united, centralised Tswana state, but by the time of the arrival of colonialism in the region these clusters had not yet 
crystallised into a strong centralised monarchy or kingdom, like the types that developed in Britain or Zululand, for example.

Prior to colonialism, the Tswana economies were relatively self-sufficient, autonomous and ecologically sound, production was responsive to the opportunities offered by the environment and its limits were the limits of its technology (Parson 1985). The Tswana traditional land tenure system vested the control of the land in the chief (kgosi) who was the custodian and trustee and was supposed to administer it in the best interests of all his subjects. The chief allocated residential and arable land to wards (boroughs), and the ward headman (the chief's representative) would then apportion land among male heads of households for the purpose of building homes, cultivation and grazing cattle. People produced a balanced diet of sorghum porridge, milk, the meat of both domestic and wild animals and vegetable dishes made from crops and wild plants. Clothing was made from animal skin and was decorated with beadwork, iron, copper and bone ornaments. Household items such as baskets, clay pots, mats, bowls and pails, spoons, cups, scoop and bottles, iron-bladed hoes, spears, axes and knives, were all home-made (Schapera 1984). To say the Tswana economy was self-sufficient and autonomous does not mean that the Tswana practised an autochthonous type of economy that was insulated from any outside contact. On the contrary, archaeologists and historians are agreed that evidence exists of 'international trade', especially with the eastern coast of Africa in goods such as furs, ostrich feathers and ivory, and that some of these goods went as far as China (Parsons 1985). Parsons (1977) provides evidence of a vibrant economy based on long distance trade in the Shoshong area of Gammangwato.

The Tswana's first contact with Europeans began at the beginning of the nineteerith century. Sillery (1965) puts it at around 1801 when an expedition headed by P.J. Trutter and William Somerville visited the Tlhaping at their capital in Ditlhakong. These two were followed by Henry Lichtenstein in 1805 and William Burchell in 1812. Schapera (1984) puts it at around 1816 when that the agents of the London Missionary Society arrived. Another recorded contact was in 1826 when the Ngwaketse chiefs, who were at war with Bakololo, tried to buy firearms from two European travellers. The arrival of the missionaries from the London Missionary Society in the 1840s brought about sustained and continuous contact between Tswana and Europeans. By the end of the 1850s, Tswana karosses, ivory, ostrich feathers, and other products were reaching European markets by way of traders and merchants in the Cape Colony. At the same time, European consumer items were appearing in Tswana towns and villages. According to Parsons (1977), in the 1870s, Shoshong was an essential 'entrepot' between Southern and Central 
Africa. It had a white 'trader ward' of forty people, including six women and thirteen children. The white trader ward (that is a predominantly European section of the village) also had permanent trading stores and had replaced the Kgotla as a market place. Parsons points out that towards the end of the $1870 \mathrm{~s}$, Shoshong had nine stores and exported about seventy-five tons of ivory culled from 12,000 elephants, with export earnings of about 30,000 pounds per annum. However, with the advent of colonialism, this trend was reversed by the arrival of the British South Africa Company (BSAC) on the scene. The BSAC was established by a Royal Charter in 1889 and given powers to occupy territory, enter into diplomatic relations and carry out military expeditions. The company had the backing of financial institutions in London and overlapping ownership by its shareholders in the newly opened diamond and gold mines in South Africa gave it a new monopoly status in the territory (Parsons 1977).

The Tswana continued to live as politically independent and yet militarily weak lineage clusters until 1885 . These divisions within and between the Tswana had made them vulnerable to outside aggression. As far back as the 1850s these militarily weak clusters of Tswana chiefdoms had found themselves caught in the crossfire of rivalries and conflicts between the British, the Germans, and the Boers. These rivalries and conflicts were an outcome of the growing competition for land by these powers. The main threat to Tswana chiefdoms came from the Boer Trekkers who sought to destroy any barriers to their future expansion into new territories to the north. The first conflict came in 1852 when a Boer commando raided the Kwena town of Dimawe and took many prisoners (Sillery 1965; Maylam 1980). According to Maylam, David Livingstone and Chief Sebele approached the British government for protection but to no avail. In 1857 a Boer commando, who claimed that Batlhaping had stolen some cattle and horses from them, raided Batlhaping. All this time, while the Boers continued to raid the Tswana chiefdoms, and the Transvaal government condoned these unscrupulous acts of its subjects, the British government gazed indifferently at the plight of the Tswana, ignoring even the strong appeals for protection from the Tswana chiefs and British missionaries (Maylam op cit., p 18). This indifference was, however, to change dramatically after the defeat of the British in the Anglo-Boer war and the arrival of the Germans in South West Africa.

\section{The Tswana under colonial rule}

Until 1885 Britain was reluctant to offer Batswana protection from the unprovoked Boer aggression, in spite of numerous requests from missionaries and some Tswana chiefs. The crucial factors in the turnaround in the British attitude towards the Batswana chiefdoms were the defeat of the British in the 
Anglo-Boer War of 1881 and the arrival of Germany in the Southern African region. Like most wars, the Anglo-Boer War was the outcome of competition for territory. The defeat of the British by the Boers left the British vulnerable and led to fears by the defeated British that the victorious Boers in the Transvaal might team up with the Germans in South West Africa (now Namibia) and the Portuguese to the East in Mozambique, to annex the central part of Southern Africa and thereby close off to the British, the route between the Cape Colony and Central Africa. To secure her base at the Cape Colony, Britain had to establish her supremacy over the interior, and to this end, 'foreign powers' would have to be firmly excluded (Maylam 1980). It was at this juncture that the potential strategic importance of this cluster of Tswana chiefdoms, as a road to central Africa, was realised by the British. These chiefdoms lay on 'the road to the north', strategically located between the Kalihari Desert and the Transvaal. Then there was Cecil John Rhodes, that infamous British man on the spot, Cape politician, empire builder and the man who founded De Beers Mining Company in 1880 . Rhodes had long called for British intervention because, in his view, Bechuanaland could provide a vital link in an unbroken imperial line running from the Cape Colony to Cairo, 'the neck of the bottle' and 'the Suez Canal' to the North. It was also a vital stepping stone for the operations of the BSAC that could serve as both a rear and forward base (Halpern 1969; Maylam 1980).

Following another Boer incursion into Tlhaping and Rolong territories in 1883-1884, a British expeditionary force under the command of Sir Charles Warren was dispatched from London in 1885 to reassert control in the area and to declare British protection over Bechuanaland south of the Molopo (called British Bechuanaland and now the North West Province of South Africa). According to Chirenje (1977), Charles Warren was instructed to move his forces up north and inform Kgosi Bathoen of Ngwaketse, Kgama of Ngwato and Sebele of Kwena, who had in the past all had their requests for British protection denied, that British protection was now going to be extended to them. Pursuant to Article 34 of the Berlin Act, which required a signatory to the Act to inform others of their action to take possession of any part of Africa, on the 27 January, 1885 Britain issued an Order in Council claiming to exercise power and jurisdiction in northern Bechuanaland. In March 885 Germany was notified that the area was now under British 'protection' and shortly thereafter a proclamation to this effect was published by the British High Commissioner to South Africa, Sir Hercules Robinson (Fawcus and Tilbury 2000).

On 2 A pril, 1885, Warren held a Kgotla meeting with the BaKwena to try to convince them that British protection was in their own interests, but was 
resisted. On 12 May, 1885 Warren held a Kgotla meeting with Kgosi Kgama who was easily persuaded. On 30 September, 1885 by Order In Council, the British established the Bechuanaland Protectorate, after much hesitation and reluctance, and only for strategic reasons to guarantee the route to the north. The 1885 Order in Council was followed by another Order in Council of 1890 that gave the British High Commissioner to South Africa the authority to govern Bechuanaland and exercise British jurisdiction over the territory. This was followed by yet another Order in Council of 1891 (the Foreign Jurisdiction Act of 1890) which gave the British High Commissioner wideranging powers to govern Bechuanaland, including the power to enact legislation by proclamation, 'except so far as the same may be incompatible with the due exercise of Her Majesty's power and jurisdiction' (du Toit 1995:2324). According to du Toit, the General Administration Proclamation of 1891 , which gave effect to the 1890 Order in Council, as well as Proclamation No. 2 of 1896 , established a system of courts and personnel modeled on the system of resident magistrates operative in the Cape Colony. In 1909, the General Law Proclamation stipulated that the Roman Dutch Law of the Cape Colony would become the common law of Bechuanaland. Chirenje (1977:132) points out that Tswana responses to British declaration of the Bechuanaland Protectorate varied from one chiefdom to another, ranging from Kgama's ready acceptance to Sebele's cautious reserve. Some seventyone years later, on 30 September 1966, the Tswana regained their independence, this time as the Republic of Botswana, an entity that includes nonTswana ethnic groups like the Kalanga, who are related to the Shona ethnic group in Zimbabwe, and the San, the first people to occupy Southern Africa.

According to Parson (1985), what the British did was to simply throw a mantle of 'protection' over the chain of Tswana states, namely Rolong,Ngwaketse-Kwena-Ngwato-Kgatla-Tawana, which were already linked together by trade and military alliances against their common enemy, the Boers, from as far back as 1852, and reaching its peak in 1881-84. It was not until the British realised that Bechuanaland as a vital link between the British interests in Southern and Central Africa was in danger of being closed off by the Boers and Germans in 1885, that they declared Bechuanaland a protectorate. That the protectorate was established at this time and not earlier when the Tswana were the ones facing military aggression from the Boers reveals that the declaration of the so-called 'protectorate' was not a humanitarian gesture, as some people have believed, but a well considered military strategic move on the part of the British. This event supports the argument by Maylam (1980) that British colonial policies sometimes combined in an inconsistent and contradictory manner. Long-term strategic issues did not al- 
ways make good business sense. Thus, if it made more business sense Britain would colonise a country, but where strategic interests carried more weight, Britain would move in and 'protect' the natives against external aggression, real or imagined (Maylam 1980).

As pointed out, not all Tswana chiefs embraced this so-called British protection, and as a result there was considerable resentment throughout the protectorate against British rule (Chirenje 1977). According to Chirenje, although Tswana chiefs did not wage an armed resistance against British rule, they nevertheless expressed reservations and even protested against the authority that British officials now exercised in their territories. The resentment regarding British rule seemed to have been so serious as to prompt the Kopong Conference in February, 1889, at which the Deputy Commissioner Sidney Shippard tried to reassert British authority. According to Chirenje, except for Kgosi Kgama's declaration of loyalty, all the chiefs expressed the wish to rule themselves without British interference. Since the British occupation of Bechuanaland was not motivated by economic gain but by military strategic considerations, it :vas the intention of the British to hand over Bechuanaland to the BSAC.

In 1895, the southern part of Bechuanaland (called British Bechuanaland and now the North West Province of South Africa) was made part of the Cape Colony. In November 1894 Cecil Rhodes made a formal request to the British government for control of the Bechuanaland protectorate in order to facilitate railway construction. In 1895, ten years after the British established their presence there, three Batswana chiefs, namely, Chief Khama of the Bamangwato, Chief Sebele of the Bakwena, and Chief Bathoen of the Bangwaketse, accompanied by Reverend W.C. Willoughby, went to England to protest in person against the intention of the British government to transfer the administration of the country to the British South Africa Company, which the British saw as a means of protecting its colonial interests in the region at no cost to the public purse (Colclough and McCarthy 1980). The BSAC was to be authorised not merely to pursue its commercial interests in both Bechuanaland and Southern Rhodesia, but also to administer these territories and maintain law and order. At first the chiefs were not successful as the Colonial Sec;etary, Joseph Chamberlain, told them that he considered himself bound by the promises that his predecessor had made to the company. It was at this juncture that the chiefs toured Britain and appealed directly to British public opinion. In the face of strong public support for the Tswana chiefs, the plan to transfer Bechuanaland to the BSAC was put in abeyance, and the Colonial Secretary agreed that the Tswana Chiefs 
would rule their own people 'much as at present', but under an officer who would receive his orders from the Secretary of State (Samatar 1999).

Notwithstanding the points raised above that Bechuanaland had little to offer Britain in the form of raw materials and markets, the British colonial state administrators' attitude towards the administration of the 'protectorate' was not significantly different from what was happening elsewhere in the British Empire. As already pointed out, the principal motivation for colonialism was economic, and the actions of the British colonial state towards the 'natives' emanated from the logic of capitalist accumulation as it unfolded in Britain in particular, and Europe in general. Because capitalism is about competition and elimination of rivals, it is perhaps not surprising that the colonial state, acting at the behest of the metropolitan bourgeoisie, found itself on the side of white settlers in blocking the efforts of the Africans to accumulate. The colonial state officials always exercised their administrative powers in such a way as to create, empower, consolidate and protect European commercial interests (Kennedy 1988). This is the point to which I now turn.

\section{Colonial capitalism and the underdevelopment of Bechuanaland}

As Rodney (1972) has argued, the general tendency of colonialism was to subvert and subjugate colonised societies, to retard their economic progress and destroy the material base of the indigenous ruling class. The applicability of this thesis to Botswana is however questioned by Steenkamp (1991), who argues that with reference to Botswana, colonialism did not retard the development of the colony, but rather that it was the development of capitalism that was retarded, especially in the period before 1929. Steenkamp argues that the retardation of capitalist development, and by extension the development of Bechuanaland, arose from the opposition of indigenous classes and the negative attitude of the colonial state officials towards capitalist enterprise. Steenkamp argues that colonial state officials often drew on the values of feudalism rather than capitalism and sought to preserve the precapitalist order by protecting it from the 'dangers' of capitalist development, were hostile to commercialisation, affirmed the communality of peasant production, and rejected the destructive effects of individualistic tendencies of capitalism. Steenkamp cites Jules Ellenberger, Bechuanaland Resident Commissioner from 1923 to 1928 , as an example of such negative colonial state attitudes towards capitalist development in Bechuanaland. Ellenberger was of the view that capitalist development threatened native interests by increasing pressure for transfer of Bechaunaland to South Africa. 
According to Steenkamp, because of domestic pressures from the chiefs and the imperial ideology that he dubs 'anti-capitalism' or 'autocratic paternalism', Bechuanaland missed two opportunities of embarking on capitalist development in the 1890s. These occasions were first, when the BSAC was not given formal control of Bechuanaland (to transform it into a white settler state based on capitalist agriculture), and second, when chiefs resisted attempts to transfer Bechuanaland to South Africa after 1910. Steenkamp argued that this prejudice against commerce made colonial state administrators unlikely to be 'modernisers'. His view is that from its inception, far from reinforcing underdevelopment, colonialism launched a process of development and that later colonial officials like Charles Rey accelerated rather than retardes this process and laid the foundations for Botswana's postcolonial economic development.

The problem with Steenkamp's approach is that he is looking at a very limited time frame 1929-1939, whilst the roots of capitalism as a world system were planted several decades before. At the same time, it is important to note that capital is much more powerful than the motivations of any individual, even one with 'good intentions' such as Charles Rey. Even if Rey had good intentions towards the welfare of the 'natives', he was working very much within the parameters and structure of a system whose logic and laws of motion outweigh the benevolence of individuals. The other problem with Steenkamp's interpretation is that he uses an approach by Bill Warren, which was in itself based on a limited number of case studies and is therefore methodologically flawed. As several authors (notably Rodney 1972; Taylor, 1979) have convincingly argued, the general tendency of capitalism is to subvert, subjugate and subsume other modes and forms of production to its own requirements. The empirical evidence presented in the discussion that follows shows that like everywhere else, colonial capitalism subverted and underdevelopec the Tswana socio-economic structure. What is more, the British colonial officials, including Charles Rey, played a crucial role in this subversion. In Botswana, this subversion was mainly through the migrant labour system precipitated by the Hut Tax, the unequal exchange in cattle trading, and in trade licensing.

\section{The Hut 'Tax and the migrant labour system'}

Taxation can be defined as a compulsory levy or a financial liability imposed on individual or groups on an individuals or corporate entities for the purpose of generating public finance. In addition, those taxed have to pay the sums irrespective of any corresponding return of services or goods by the state(Bhatia 1987). Tax liability also assumes that those so taxed enjoy income from certain specified sources or carry on economic activities which 
have been chosen for taxation. In modern economies, the rate of tax is related to the ability to pay. As pointed out above, Britain was not attracted to Botswana by economic resources that she could exploit, but by strategic considerations. This conflicted with the need to maintain financial prudence in the absence of exploitable resources. To resolve this problem, Bechuanaland's colonisation had to be self-financing. In order to raise funds to meet recurrent expenditure, the colonial government decided to introduce the Hut Tax, a tax that was levied per annum in respect of every dwelling occupied by a native (Schapera 1947).

The Hut Tax was a single tax system also known as the poll tax. Poll tax was imposed on persons simply because they are there in the society, and not because of any income. Because the tax was not based on the ability to pay, the introduction of the Hut tax in 1899 precipitated an outflow of Tswana labour to South African mines and farms and began a process of colonial capitalist underdevelopment of Bechuanaland. As the recurrent costs of the colonial administration escalated, the colonial administration doubled the rate of the Hut Tax, and in 1919 another tax called the Native Tax was introduced to supplement the Hut Tax. This tax was in the form of a surcharge of three shillings on each pound paid in Tax. In 1932 the Hut tax and Native Tax were amalgamated and were called the African tax, payable by every Africen male of an 'apparent age of 18 or above' (Schapera 1947).

According to Schapera, by 1943 there were about 33,000 Batswana workers in South A frica consisting of about 29,500 men and about 3,500 women, of whom 720 were living with their husbands. This included about 10,000 military conscripts in the f. frican Pioneer Corps and Native Military Corps. The highest proportion of these workers was in the Witwatersrand and Kimberly areas, the heartland of South African mining industries. A part from the Witwatersrand and Kimberley mines, African labour was being recruited in the Bechuanaland Protectorate for mining companies in Rhodesia and to a small extent for Monarch Mine in the Tati District inside Bechuanaland. The effects of this outflow of Tswana labour to South Africa were devastating and revealed an extensive subversion of Tswana economy and society by the British colonial state. Labour migration generally subverted and undermined the traditional forms of economic activity as many able bodied men and women were no longer available to attend to the routine tasks of animal husbandry and arable production. Schapera points out that cattle were scattered with no one to look after them, fields were left to decay and covered with veeds, and huts were left unattended and tumbled down. At the level of the community, people experiencing cultural shocks, such as when returning migrants shunned involvement in agricultural activities. These returning 
migrant workers had also undergone attitudinal changes and had become more individualistic and rebelled against conventional obligations to the community. The traditional family unit had its own share of cultural shock as husbands deserted their wives, wives became unfaithful to their absentee husbands, sons deserted their families, and pre-marital pregnancies and single parentage became common as eligible young men were now almost permanently absent from home (Schapera 1947).

The break-up of the Tswana society and its economy seems to have been so serious that concerns were even raised at several meetings of the Native Advisory Council where the colonial officials were asked to do something to stop young men leaving the country (Schapera, op cit). In 1938 a report on the cattle industry also stressed the need to take steps to protect the industry from the harmful effects of excessive recruitment of labour as the recruitment drive removed the most active and vigorous sections of the population as well as the beneficial effects exercised by this section on the cattle industry. Tswana society, which was economically self-sufficient albeit within the contours of a pre-industrial mode of production, was becoming more and more dependent on the capitalist economy and could no longer sustain itself. This is clearly demonstrated by the 1938-42 trade figures which show that in these years the value of imports to Bechuanaland was about 460,000 pounds whilst the value of export earnings in the same period was about 242,500 pounds, reflecting a balance of trade deficit of about 217,000 pounds (Schapera 1984).

The introduction of the Hut Tax has led to a great deal of controversy regarding the motives for British actions. We now know from the evidence presented above that in declaring the cluster of Tswana chiefdoms a protectorate, the British actions were less than honourable. There is compelling evidence that shows that Britain 'protected' Bechuanaland not for the sake of its people but because of strategic military interests. With regard to the Hut Tax, even if it can be assumed that the motive behind its introduction was solely to generate revenues internally for the administration of the "protectorate', especially because available evidence does not show any intention on the part of the colonial state officials to induce the outflow of cheap 'native' labour to South African mines and farms, sufficient circumstantial evidence exists to show that the colonial officials were well aware that the introduction of such a tax would necessarily induce such an outflow of labour to South Africa.

In the first place, the tax was not based on ability to pay and required cash payments, rather than payment in kind. The colonial officials were well aware that the economy of the country was predominantly based on subsistence agriculture, and that employment opportunities were limited. While richer 
famil :s could sell livestock cheaply to pay the tax, the tax burden for the poorer families forced them to seek employment in South A frica. In the second pisce, the law that introduced the Hut Tax, Proclamation 10 of 1899 , provided that anybody convicted of failure to pay tax within three months after the due date would be liable to a fine of five pounds, and in default of payment, to a term of imprisonment with or without hard laboul for a period not exceeding three montis (Schapera 1947). In the third place, after the imposition of the Hut Tax, the colonial state enlisted the support of the chiefs by offering them a 10 percent commission on the amount of tax collected from their subjects. According to Schapera (op cit), the chiefs were also continually harassed by the colonial state if their tax returns fell below expectation. Some chiefs saw this as an opportunity to accumulate, since the more tax returns the chiefs brought, the more money they received in commission. This led to abuse of office by some chiefs, like Seepapitso I who issued his own 'proclamation' in 1911 that any man who was unable to pay tax would be sent away to work in the mines. The migrant labour system assured the British and South African mining interests of a fairly steady supply of cheap labour. The migrant labour system was good business because it was cheap to maintain as part of the cost for the reproduction of the migrant worke ' was met from the rural peasant economy of the villages. Although the South African mining industry was an extension of metropolitan capitalism, it was subject to pressures from other fractions of South African capital concerning the supply and price of labour. The main area in which it was easier to extract surplus vilue was in minimising the costs of labour and paying far below the cost of its reproduction. Schapera (1947) quotes a report by the Mines Native Wages Commission as saying that the maintenance of a system under which the South African mines were able to obtain unskilled labour at a rate below that paid in the market depended on the existence of a migrant labour system, which should be encouraged. According to the Report, if subsidiary means of existence were to disappear, that would produce permanent workers who would demand more wages for their reproduction. It would seem that the solution lay in widening the catchment area of a cheap labour supply and extracting profit through means other than competition (Parsons 1985).

Flom the foregoing it is clear that even if it was not the intention of the colonial officials to induce labour migration in Bechuanaland, the weight of the cir uumstantial evidence of the points mentioned above shows that there was certainly a very curious coincidence or overlapping of interests between the colonial officials and the mining houses in South Africa, which comprised very significant British investment. The advantages of the system to 
the colonial state and mining interests were also pretty much obvious: the Hut Tax had enabled the colonial administration to balance its budget, which incidentally comprised its own recurrent administrative costs (Massey 1978). According to Hermans (1974), for many years, the Bechuanaland Protectorate Police, which consisted of British commissioned and non-commissioned officers and Basutho enlisted men enjoyed not only the lion's share of the annual budget allocations, but at a certain point also accounted for up to 90 percent of all established colonial government posts. That the migrant labour system was definitely advantageous to the colonial state is captured in the words of Charles Rey that the Hut Tax 'will help natives to get a little money which they badly need, and will enable the administration to get a certain amount of additional hut tax which they need no less badly' (Massey 1978, emphasis added). What this means in effect is that the Tswana were manipulated to finance their own colonisation!

\section{Colonial subversion of 'native' commercial activities}

Although the migrant labour system was perhaps the most critical mechanism used to subvert the Tswana economy and society, it was but one element in the totality of an imperialist strategy to subvert and subjugate the Tswana. Whilst before colonialism the Tswana economy was relatively self sufficient, by the early 1940s Bechuanaland was already experiencing balance of trade deficits, as a result of a slowdown in domestic production brought about by the outflow of productive labour to the mines. The long-term effects of this were the destruction of both the material and social basis for indigenous capital accumulation.

A crucial factor in the destruction of the Tswana's indigenous economy was the attitude of the colonial officials towards the entry of Batswana into trade and commerce and the introduction of discriminatory business and commercial practices. The Credit Sales to Natives Proclamation (1923) is perhaps a good example of this restriction. This Proclamation restricted the borrowing capacity of 'natives' to 35 pounds a year, restricted Batswana's economic activities to agriculture, and reserved 'modern' commercial activities for Europeans and Indians. By the early 1930s, Europeans operated about 131 of the 155 trading licences, the rest being operated by Indians. The same Europeans were also the principal wholesalers in all of Bechuanaland and had exclusive trade monopolies in places like Batawana, Kgalagadi, Ghanzi, and Gaborone districts as well as in the Tuli Block. The white traders also used their stores as cattle sales stations and labour recruitment centres (Best 1970) According to Best, those Batswana who wanted to enter into commerce in the 1930s were faced with considerable opposition from the white settlers. For example, in 1928 the brother of the Barolong Chief had his 
application rejected on the basis that he was 'under capitalised', and that the area was sufficiently served by the existing white traders.

The white-owned trading stores further played a major role in the exploitation of African farmers through an unequal exchange system known as 'good fors' (Wylie 1990, Morapedi 2004). In this exchange system, an indigenous farmer would bring his cattle or bags of grain to a white-owned trading store for sale and would be given a slip of paper indicating that his beast or bag of grain was 'good for' a certain amount of imported European goods such as earrings, bracelets, tea, sugar, soap, and cloth. But a slip of paper written 'good for' for the purchase of goods worth say one pound could be exchanged for goods worth far less than that (Wylie 1990). This unequal exchange system, which tied Tswana producers to certain store owners, enabled these store owners to make huge profits because Tswana consumers were compelled to buy overpriced goods (Morapedi 2004). According to Morapedi, complaints against the use of 'good fors', especially in 1930s and 1940s, came from all parts of Bechuanaland, with Ngamiland, Gantsi and some parts of central Bechuanaland being the hardest hit. One of the complaints against the system, apart from the fact that it enabled the traders to undervalue African products and overvalue their own consumer goods, was that in certain instances, traders refused to give African producers cash for their products, forcing some of them to go to the mines as labourers for the purpose of paying tax.

Not only were Batswana faced with the problem of subversion of their economy through enforced labour migration and an unequal exchange system of 'good for', but the financial burden of running the territory also fell firmly on their shoulders. Whilst the Batswana contributed almost 40 percent in direct taxation and even more indirectly through tribal levies, the European traders who controlled the trading and commercial sector were not taxed on their profits until the mid-1930s. However, Steenkamp (1991:299) argues that while traders may have bought cheap and sold dear, they presented the Tswana with another strategy to escape famine and afforded them flexibility in the deployment of resources, which offered the potential for accumulation.

Another glaring exampie of the colonial administration's policy of subversion of 'native' attempts to accumulate in preference to white traders is recounted in detail by Parsons (1975). According to this Parsons, in 1909, Chief Khama of the Bamangwato was invited by a Serowe-based trading partnership, Garrett, Smith and Co., to join them and help re-capitalise the company. Khama viewed this invitation as an opportunity for him, not in his personal capacity but as the chief, to diversify the economy of his territory, 
following persistent drought and epidemics that destroyed both crops and livestock. After re-capitalisation, principally by Khama, the partnership moved in to take over or support the accounts of smaller trading outlets in the Ngwato and Tawana Reserves and also saved a number of other smaller traders fiom bankruptcy. According to Parsons, in the process Garrett, Smith and Co. became the largest trading concern in Gammangwato and a threat to the Bechuanaland Trading Association (BTA), a large scale enterprise with interests outside Bechuanaland and linked to the BSAC in Southern and Northwestern Rhodesia. The success of Garrett, Smith and $\mathrm{Co}$. soon aroused the indignation of one Paul Jousse, the local BTA white manager. Jousse started a vicious campaign to discredit Garrett, Smith and Co., claiming that the company was a monopoly and that consumers were boycotting his stores because of Khama's royal influence, forgetting that it was the same BTA that had enjoyed the monopoly of being the largest concern and former Khama's bankers. Eventually, at the beginning of 1916, in what can only be characterised as an act of 'political-commercial conspiracy' between the Colonial Office and local settler commercial interests, Khama was instructed by the Acting Resident Commissioner to withdraw from all trading interests, much to the delight of the BTA. Khama was not allowed to sell his shares, but the company was to be wound up, and its stock sold off piecemeal, as if it were a bankruptcy case. It can be argued that forcing Khama to withdraw from business and winding up his company as if it was insolvent reflected the political pressures to subordinate Bechuanaland to outside interests, notably South Africa, but also British (Parsons, op cit).

The growing demands of Batswana to enter trading led to the creation of a 'restricted dealer licence' that permitted Batswana to trade solely in the socalled African reserves outside 'European' places like Lobatse, Francistown and Gaborone. In other words, there were now two types of trading licences in Bechuanaland, namely the general trading licence that was reserved for white traders, and the restricted dealer licence for native Batswana. The restricted dealer licence limited the turnover of native trade and prevented native trading stands from being closer than five miles to a white controlled general dealer. In 1968, two years after Botswana's formal independence, of the 439 general trading licences issued, only 31 percent were to Batswana, who also held 90 percent of restricted general dealer licences (Best 1970). At the same time, the rejection of the 'natives' applications for trading licences on the basis that they were undercapitalised and lacked experience needs to be examined critically and should not be taken at face value. It is not necessary to discuss at any length alleged lack of experience, suffice to 
point out that experience is not something that comes just ready made to an individual, but has to be acquired on the job.

\section{The role of the tribal treasuries}

The Tribal Treasuries in Bechuanaland were established under the Treasuries Proclamation No.35 of 1938 (Muzorewa 1978). The main sources of revenue for Tribal Treasuries included the Graded Tax, Native Tax, court fines and school fees, sale of school books and hunting permits. Expenditure included salaries and wages of native authorities, tribal officials and employees including teachers, extension workers and labourers as well as capital and maintenance costs of school buildings, boreholes and maintaining roads (Shapera 1984). Triba! levies such as the 1941 War Levy were also imposed from time to time as temporary measures to provide funds for specific purposes. The War Levy was imposed throughout the territory and part of the money went into British government revenues, a part was used to provide gifts for men serving on the front with the African Pioneer Corps, and the balance was loaned interest-free to the British government, presumably to finance a war effort that had nothing to do with the Bechuanaland Protectorate (Schapera 1947).

Even though these Tribal Treasuries were created for the 'better management' of the territory's finances, they were also used to further subvert and subjugate the economy of the Tswana. Although the mandate of the Tribal Treasuries was social development, austerity measures that were introduced by the colonial administration ostensibly to keep the Tribal Treasuries afloat during hard times had the effect of curtailing development expenditure. This was because the colonial administration required that the Tribal Authorities should maintain surplus revenue equal to six months of ordinary expenditures. They were also legally required tỏ set aside in a Special Reserve, one half of their yearly revenue (Muzorerwa 1978). According to Hermans (1974), by the 1946/47 financial year the reserves stood at 346,000 pounds and by 1952 the reserves stood at about 419,000 pounds. The reasons for this requirement were that the sources of revenue for Tribal Treasuries were precarious because they depended wholly on taxes, which in turn depended on money income which tended to fluctuate depending on a number of factors. Muzorewa (1978) argues that there was no doubt the requirement was unreasonable and the real reserves were far in excess of statutory requirements.

The implications of such austerity measures were obvious: the tribal authorities did not do as much as they could have done in terms of developing physical and social infrastructure, as, for example, only a few major development projects could be undertaken and only a few teachers could be employed. What is even more significant is that these austerity measures must 
have had a contractionary effect on the economy of the whole of Bechuanaland because the requirements applied to all Tribal Reserves across the colony. In addition, the savings that were squeezed out of the Tswana economy through taxes were poured into the banks of the more developed economies of South Africa and Britain at very low interest rates. This clearly indicates that even if it was true that some individual 'native' applicants were undercapitalised, sufficient financial resources existed in the form of Tribal Treasuries deposits, and that these could have been utilised for the development of the 'protectorate' had there been a political will on the part of the colonial officials.

\section{Arrangements for political independence}

It is now accepted by several African scholars (notably Chinweizu 1987) that the Second World War can be regarded, perhaps with the benefit of hindsight, to have been a blessing in disguise for Africa. This internecine war between the latecomers, Germany and Italy, on the one hand, and the early entrants, Britain and France on the other, revolved around access to raw material supplies and markets for European industrial products in both Africa and other parts of Europe (Chinweizu 1987). The war resulted in almost the common ruin of major European colonial masters and when the war ended, all these powers were greatly debilitated and militarily exhausted. The impact of the war on the morality of colonial rule was considerable and the colonised and the colonisers realised that the ground had shifted (Chazan et al 1999). Because of the devastation of the war that had just ended, there was obviously no public support for further military engagements, especially in far-flung places like Africa. This gave impetus to the anti-colonial struggles that expressed themselves in a variety of forms such as urban discontent, rural revolts and messianic religious formations. The principle of political independence was recognised as necessary to avert prolonged struggles for independence such as those in Algeria which were proving too costly in both men and human resources. It became necessary to make arrangements for the political independence of the colonies. As the colonial administrators prepared to grant independence to their colonies, they also identified their heirs from within the nationalist movements. The nationalist movements themselves were quite heterogeneous and the political parties that emerged differed from each other in terms of social composition, ideological inclination, recruitment patterns, strategies and tactics (Chazaan et al. 1999). Competition and conflict from within the nationalist movement created a situation whereby not only did the nationalist parties compete with each other but some of them negotiated with the colonisers for favourable arrangements that would enable them to win the first independent elections. This lack of unity within the nationalist movement helped the departing colonisers to iden- 
tify their political heirs. The qualification to be identified as an heir was to be a 'moderate' and plans were made to marginalise those identified as 'radical'. In negotiations with the moderates, special provisions were introduced to take into account not only the demands of the moderate nationalist, but also the interests of the coionisers. In the end, when independence came, it was not really a fundamental break with colonial values and interests, but was more of a compromise package (Chazan et al. 1999).

In Bechuanaland, the 'radical' nationalists organised themselves into the Botswana People's Party (BPP). The BPP was formed in December 1960 by a group of nationalists, some of whom had been political activists in South Africa before the banning of the African National Congress and the South African Communist Party. The BPP mobilised around the issue of racial discrimination and social inequality along racial lines, a characteristic feature of colonial government, and demanded a boycott of white-owned businesses, early independence, Africanisation of the civil service, and nationalisation of the land. The ideologicalodifferences that had led to a split in the nationalist movement in South Africa crept into the BPP and its leaders started making accusations and counter accusations against each other. Eventually, the party split into two smaller groupings. But its nationalist rhetoric had sufficiently alarmed the colonial administration and spurred it into identifying an alternative moderate nationalist party to lead Botswana to independence (Mogalakwe 1997). The colonial officials had warned that the BPP was proCommunist and therefore a threat to the British interests in Bechuanaland. The 'moderate' nationalist party chosen was the Bechuanaland Democratic (BDP) Party, headed by Seretse Khama, who had recently returned from exile. Seretse Khama had previously fallen out with the British because he had married a white Briton, something that the South Africa leaders were not happy with. Gossett (1986) argues that one of the BDP's favourite tactics, and one that must have endeared them to the colonial authorities, was their habit of always crossing the BPP picket lines when the BPP was organising the boycott of white businesses.

After its formation in 1962, the BDP received unqualified logistical support from the colonial administration as well as considerable financial and organisational support from European and Asian business communities. Most of the leaders of the BDP were members of the Legislative Council, and between the times of its formation and the first general elections in 1965, the BDP was treated as a government in waiting. When the 1965 election came, the BDP was, de facto, already in power by virtue of the fact that most of its leaders were already in government under the Legislative Council. Seretse Khama, who was one of the four executive members of the Legislative Council, became the first Prime Minister and later the President of Botswana. 
Seretse Khama died in 1980, and was replaced by Vice President Quett Masire, When Masire retired in 1997 he was replaced by a successor of his choice, Vice-President Festus Mogae. It is anticipated that when Festus Mogae leaves office he will be succeeded by his Vice-President, lan Khama, the son of Botswana's first president.

\section{Conclusion}

The foregoing analysis reveals that although Bechuanaland was supposed to be a protectorate rather than a colony, the colonial policies subverted the economic activities of the people that they were protecting. Before the advent of British colonialism, the Tswana economy was relatively robust and self-reliant with a fair amount of international trade going on, especially in luxury goods like ivory, ostrich feathers and furs. The limitations of the economy were really the lim:its of the technology that was available at that time. With the advent of colonial capitalism, one would have expected that the Tswana economy would get a boost to its productive forces from the infusion of new technological innovations from the industrial revolution. Instead the opposite happened. Instead of coming with technological innovation, colonial capitalism subverted the Tswana economy and society as the territory was incorporated into the world capitalist system on very unequal terms. The migrant labour system led to economic collapse as able bodied men were forced to go to the mines, the colonial state introduced a regressive tax system that squeezed surplus from the people, and the white traders introduced an exploitative system of unequal exchange built on the 'good for' system. The colonial officials also introduced a legal and administrative regime that curtailed or marginalised the commercial activities of the natives, and the tribal treasuries were instructed to implement financial austerity measures, despite the fact that their deposits were a surplus squeezed from the people through taxation. The combined effects of all these had a contractionary effect on the economy and prevented indigenous or domestic capital formation by the natives for the entire colonial period. At the time of independence it was clear that 90 years of colonialism had stunted and distorted Botswana's economic growth and blocked the development of the productive forces of the country and domestic capital formation. The modern sector of the economy, especially commercial agriculture and commerce, was in the hands of white settler capitalists who were a part of the metropolitan capitalism based in South Africa and Britain, and there was no industrial and manufacturing base to move the economy forward. It was at this time that the departing colonial state made political independence arrangements with the fledgling Tswana petty bourgeois elements in the Tswana nationalist movement. In order to safeguard the interests of the white settler capitalists and make 
sure that independent Botswana remained within the capitalist camp, it was necessary to bring on board the petty bourgeois fraction of the Tswana nationalists.

The claracteristic feature of this Tswana petty bourgeois was that it lacked both the material resources to initiate economic growth and the political experience to maintain its hegemony over the postcolonial Tswana society. More importantly, this petty bourgeoisie could not compete successfully with settler capitalists. The only resource that this petty bourgeois had was the control of the new state and its resources. It was the new postcolonial state that became a launching pad to grow and nurture this petty bourgeoisie to enable it to grow into a "national bourgeois' that colild participate in the world capitalist system, although junior to the metropolitan bourgeois. For this national bourgeois to succeed, it had to rely on the state, invoke the ideology of national interest, present its class interests as national interests, and interiorise them into the postcolonial state national development plans. In other words, the national development plans are really a class project by this emergent national bourgeois to accumulate, not independently but alongside and as part of the world capitalist system. The main vehicle for accumulation by this petty bourgeoisie and its elements has been the Botswana Development Corporation (BDC), a public corporation created in 1970 for the purpose of promoting an entrepreneurial class by assisting with the infusion of share capital, loans and overdraft facilities, procurement of industrial land and buildings, technical and managerial support, and provision of expert business advice and guidance, thus effectively creating a bourgeois class where none existed previously.

\section{References}

Bhatia, H. L., 1987, Public Finance, New Delhi: Vani Educational Books.

Best, A., 1970, General Trading In Botswana, 1890-1968, Economic Geography, 46, 4, pp 598-611.

Campbell, A., 1968, The Guide to Botswana, Johannesburg: Winchester Press.

Chazan, N., et al., 1999, Politics and Society in Contemporary Africa, Boulder: Lynne Rienner.

Chinweizu, 1987, The West and the Rest of Us: White Predators, Black Slavers and the African Elite, Lagos: Pero Press.

Chirenje, M., 1977, A History of Northern Botswana, 1850-1910, Fairleigh: Di kson University Press.

Colclough, C., and McCarthy, S., 1980, The Political Economy of Botswana: A Study of Growth and Distribution, Oxford, Oxford University Press.

Courcel, de G (1988) The Berlin Act of 26th February 1885, in Forster S, Mommsen W and Robinson R (eds.) Bismarck, Europe, and Africa - The 
Berlin Africa Conference 1884-1885 and the Onset of Partition, Oxford, Oxford University Press.

du Toit, P., 1995, State Building and Democracy in Southern Africa, Washington, D.C.:United States Institute of Peace Press.

Fawcur, P., and Tilbury, A., 2000, Botswana: Road to Independence, Gaborone: Botswana Society.

Gossett C. W., 1986, The Civil Service in Botswana: Personnel Policies and Comparative Perspectives, PhD Thesis, Stanford University.

Halpern, J., 1969, South Africa's Hostages, Basutoland, Bechuanaland, and Swaziland, Harmondsworth: Penguin.

Hermans, Q., 1974, 'Towards Budgetary Independences. A Review of Botswaita Financial History 1900-1973', Botswana Notes and Records, Vol.6 (89-135). Kennedy, P., 1988, African Capilalism, The Struggle for Ascendancy, Cambridge: Cambridge University Press.

Legassick, M., 1969, 'The Sotho-Tswana Peoples before 1800', in L. Thompson, ed., African Societies in Southern Africa, London: Heinemann.

Lenin, V. 1., 1968, Imperialism: The Highest Stage of Capitalism, Mescow: Progress Publishers.

Massey, D., 1978, 'A Case of Colonial Collaboration: The Hut Tax and Migrant Labour', Botswana Notes and Records, Vol. 10 (95-98).

Maylam, P., 1980, Rhodes, the Tswana, and the British, Westport, CT: Greenwood Press.

Mogala! we, M., 1997, The Slate and Organised Labour in Botswana, 'Liberal Dewiocracy in Emergent Capitalism', Aldershot: Ashgate Publishing.

Morapedi, W. (2004), Cattle, Trade and the Peasantaries of Botswana: The case of Cantsi and Ngamiland, 1938-1953, Pula, Botswana Journal of African Studies, Vol. 18, 2 (95-110)

Muzorewa, B. C., 1978, "The Role of Local Treasuries in the Underdevelopment of Botswana, 1938-1953', Botswana Notes and Records, Vol. 10 (113-118). Palmer, R., and Parsons, N., ils., 1977, The Roots of Rural Poverty in Ceniral and Southern Africa, London: Heinemann.

Parson, J., 1985, 'The Labour Reserve in Historical Perspective: Towards a Political Economy of the Bechuanaland Protectorate', in Picard, L., ed., The Evolution of Modern Botswana, Rex Collins.

Parsons, N., 1975, 'Khama and $\mathrm{Co}$ and the Jousse Trouble 1910-1916', Journal of African Hislory, Vol. 16, No 3 (383-408).

Parsons, N., 1977, The Economic History of Khama's Country in Botswana 18441930, in Paimer R and Parsons N (eds.) Roots of Rural Poverty in Central and Southern Africa, Berkeley, University of California Press, pp. 113-141.

Parsons, Q., and Crowder, M., 1988, Monarch of all I Survey: Bechuanaland Diaries 1929-37, Gaborone: Botswana Society, L Barber Press.

Ramasy. J et al. 1996, Historical Dictionary of Botswana, Lanham MD: Scarecrow. Rodney, W., 1972, How Europe Underdeveloped Africa, London: BogleL'O verture. 
Samatar, 1., 1999, An Africai Miracle, State and Class Leadership and Colonial Legacy in Botswana Development, Portsmouth: Heinemann.

Schapera, I., 1947, Migrant Labour and Tribal Life, Oxford: OUP.

Schapera, I., 1984, The Tswana, London: International African Institute.

Sillery, A., 1965, Founding a Protectorate History of Bechuanaland, 1885-1895, London: Mouton and $\mathrm{Co}$.

Steenkamp, P., 1991, 'Cinderella of the Empire?: Development Policy in Bechuanaland in the 1930s', Joumal of Soulhein African Studies, Vol. 17, No. 2. Taylor, J., 1978, 'Mine Labour Recruitment in the Bechuanaland Protectorate', Botswana Notes and Records, Vol. 10 (99-112).

Taylor, J.G., 1979, From Modernisation to Modes of Production. A critique of the Sociologies of Development and Underdevelopment, London: Macmillan.

Tlou, T., 1974, 'The Nature of Batswana States: Towards a Theory of Batswana Traditional Government - The Tawana Case', Botswana National Records, Vol. 6, pp. 5775.

Wallerstein, I., 196 I, Africa, the Politics of Independence: An Interpretation of Modern African History, New York: Vintage Books.

Wylie, D., 1990, A Little God: The Twilight of Patriarchy in a Southern African Chiefdom, Johannesburg: Witwatersrand University Press. 